\title{
PENGARUH BRAND IMAGE DAN PACKAGING GETUK SINGKONG TERHADAP MINAT GENERASI MUDA MENGKONSUMSI MAKANAN TRADISIONAL DI JABODETABEK
}

\section{The Influence Of Brand Image and Packaging of Cassava Cracks On Young Generation Interests Consuming Traditional Food In Jabodetabek}

\author{
Tri Djoko Sulistiyo ${ }^{1)}$, Christoforus Kevin ${ }^{2)}$ \\ ${ }^{1)}$ Program Studi Hospitaliti dan Pariwisata, STP Trisakti \\ ${ }^{2)}$ Program Studi Hospitaliti dan Pariwisata, STP Trisakti
}

12 Desember 2019

\begin{abstract}
Tourism Industry nowadays is developing rapidly, this must be supported by the development in the field of traditional culinary industry. But in fact, today's traditional culinary has begun to be forgotten and replaced by fast food or modern food. This research was aimed to analyzed the influence brand image, packaging, brand image and packaging of getuk singkong to the interest of consuming traditional food of young generation. The research methodology that will be used is quantitative. This study use the student of Trisakti School of Tourism for respondents. From the result of this research, it can be concluded that Brand Image getuk singkong will increase by 0,496, Packaging getuk singkong variable will increase by 0,399, and this also supported by the ability of Brand Image and Packaging getuk singkong variables of 65,8\% to influence the interest of young generation to consume traditional foods. Based on the result of this study is also suggested to the business influencer to pay more attention to all aspects that exist within the existing product and several factors that can improve the quality of existing product.
\end{abstract}

Keywords: Brand Image, Packaging, Interest of Consuming Traditional Food, Young Generation, Getuk Singkong

\begin{abstract}
ABSTRAK
Perkembangan industri pariwisata saat ini sangatlah pesat, hal ini juga harus didukung dengan adanya perkembangan di bidang industri kuliner khususnya kuliner tradisional. Namun pada kenyataannya, saat ini kuliner tradisional sudah mulai terlupakan dan tergantikan oleh makanan cepat saji atau makanan modern. Penelitian ini bertujuan menganalisis pengaruh brand image, packaging, serta brand image dan packaging terhadap minat mengkonsumsi makanan tradisional generasi muda. Adapun metode penelitian yang akan digunakan adalah kuantitatif. Penelitian ini menggunakan responden adalah mahasiswa dan mahasiswi Sekolah Tinggi Pariwisata Trisakti. Dari hasil penelitian ini dapat disimpulkan bahwa brand image dan packaging getuk singkong mempengaruhi minat generasi muda mengkonsumsi makanan tradisional, dimana pada setiap kenaikan satu satuan maka variabel Brand Image getuk singkong akan meningkat sebesar 0,496 dan variabel Packaging getuk singkong akan meningkat sebesar 0,399. Dan hal ini juga didukung kemampuan variabel Brand Image dan Packaging getuk singkong sebesar 65,8\% untuk mempengaruhi variabel minat generasi muda mengkonsumsi makanan tradisional. Berdasarkan hasil dari penelitian ini juga disarankan kepada pelaku bisnis untuk dapat memperhatikan segala aspek yang ada didala m produk yang ada serta beberapa faktor yang dapat meningkatkan kualitas produk yangada.
\end{abstract}

Kata kunci: Brand Image, Packaging, Minat Mengkonsumsi Makanan Tradisional, Generasi Muda, Getuk Singkong 


\section{PENDAHULUAN}

\section{a.Latar Belakang}

Perkembangan industri pariwisata saat ini tumbuh pesat, jumlah wisatawan yang datang ke Indonesia cukup meningkat. Berdasarkan data statistik Kementerian Pariwisata bulan Desember tahun 2017 jumlah kunjungan wisatawan mancanegara yang masuk ke Indonesia melalui 19 pintu masuk utama di Indonesia mencapai 14.039.799 jiwa, angka ini cukup meningkat dari tahun sebelumnya yang hanya mencapai angka 11.579.275 jiwa pada tahun 2016 dan hanya mencapai angka 10.406.759 jiwa pada tahun 2015. Dapat kita simpulkan bahwa jumlah wisatawan yang datang ke Indonesia terus meningkat setiap tahunnya. Perkembangan industri pariwisata ini tentunya juga diikuti dengan perkembangan industri kuliner, banyak usaha dagang dan bisnis baru bertemakan makanan baru yang mengangkat makanan trend pada saat ini namun tidak ada yang membahas mengenai makanan tradisional. Indonesia adalah negara kepulauan yang didalam masing-masing pulaunya terdiri dari beberapa kota. Setiap kota atau kabupaten memiliki suatu kebudayaan yang berbeda-beda satu dengan lainnya. Salah satu kebudayaan itu adalah kuliner tradisional. Masing-masing kota atau kabupaten memiliki kuliner tradisional yang berbeda. Kuliner yang sangat beragam inilah yang menjadi salah satu daya tarik utama bagi para wisatawan untuk berkunjung ke Indonesia dan kota atau kabupaten didalamnya. Makanan tradisional adalah salah satu unsur kebudayaan yang harus terus kita lestarikan. Namun sayangnya belum ada usaha yang mengangkat makanan tradisional sebagai dasar bisnis tersebut.

Saat ini konsumen tidak hanya memperhatikan makanan hanya dari rasanya saja. Ada beberapa aspek atau kriteria penilaian tambahan yang akan mendukung ataupun menolak suatu makanan atau produk yang ada. Beberapa aspek tambahan itu adalah warna, bentuk, ukuran, aroma, trend, dan bahkan pendapat dari konsumen lain sudah menjadi salah satu tolak ukur terhadap suatu produk yang ada.

Dampak dari munculnya beberapa tolak ukur tersebut dapat kita lihat atau rasakan langsung pada makanan ataupun produk tradisional.
Produk tradisional indentik dengan bentuk, warna, rasa, dan aroma yang netral atau dapat dibilang sama antara satu dengan lainnya.

Saat ini perkembangan zaman serta perilaku generasi muda yang semakin modern mendorong minat generasi muda untuk lebih memilih mengkonsumsi western food dibandingkan makanan tradisional sehingga konsekuensinya adalah makin tergusurnya makanan tradisional. Menurut hasil survey psikografis Loewe pada tahun 2010 di Indonesia, makanan tradisional hanya menyentuh angka 20,1\% dari masyarakat konsumen Indonesia. Mereka adalah yang tinggal di desa, tidak punya banyak keinginan, sederhana dengan tingkat sosial ekonomi rendah. Untuk dapat diminati kelompok konsumen mapan, percaya diri dan berkarakter kuat serta kelompok konsumen realistis yang merupakan 28,7\% dari seluruh masyarakat konsumen Indonesia harus dilakukan upaya maksimal. (Gardjito, 2013)

\section{b.Identifikasi Masalah}

Berdasarkan latar belakang yang dikemukakan, maka dapat diidentifikasi permasalahan pada penelitian ini sebagai berikut:

1. Belum diketahuinya pengaruh brand image terhadap minat mengkonsumsi makanan tradisional generasi muda.

2. Belum diketahuinya pengaruh packaging terhadap minat mengkonsumsi makanan tradisional generasi muda.

3. Belum diketahuinya pengaruh brand image dan packaging terhadap minat mengkonsumsi makanan tradisional generasi muda.

\section{c.Tujuan dan Manfaat Penelitian}

Adapun tujuan dari penelitian ini adalah:

1. Menganalisis pengaruh brand image terhadap minat mengkonsumsi makanan tradisional generasi muda.

2. Menganalisis pengaruh packaging terhadap minat mengkonsumsi makanan tradisional generasi muda.

3. Menganalisis pengaruh brand image dan packaging terhadap minat mengkonsumsi makanan tradisional generasi muda.

Manfaat dari penelitian ini adalah:

1. Sebagai bahan informasi bagi pelaku usaha bidang kuliner, untuk dapat melakukan 
modernisasi terhadap produk tradisional lainnya supaya dapat kembali diterima oleh generasi muda.

2. Diharapkan dapat membangkitkan kembali semangat generasi muda untuk melenstarikan dan menjaga makanan tradisional.

\section{METODE PENELITIAN}

Dalam penelitian menggunakan metode yang digunakan adalah metode kuantitatif. Penelitian ini akan menguji bagaimana pengaruh brand image, packaging, serta brand image dan packaging, getuk singkong terhadap minat genersi muda mengkonsumsi makanan tradisional, melalui instrument kuesioner. Pengukuran jawaban kuesioner karakteristik demografi responden dilakukan dengan menggunakan skala pengukuran interval dan nominal, sedangakan kuesioner Brand image, Packaging, dan minat beli getuk singkong terhadap minat genersi muda mengkonsumsi makanan tradisional dilakukan dengan sistem skor menurut Skala Likert dengan 6 pilihan, yaitu:

1) Sangat Setuju Sekali (SSS) : 1,00-1,82

2) Setuju Sekali (SS) : : $1,83-2,65$

3) Setuju (S) : 2,66-3,48

4) Kurang Setuju (KS) : : $3,49-4,31$

5) Tidak Setuju (TS) : : 4,32-5,14

6) Sangat Tidak Setuju (STS) : 5,15-6,00

Kuesioner diuraikan sebagai berikut:

A. Karakteristik Demografi Responden, diantaranya: Usia, Domisili, dan Angkatan.

B. Kuesioner Brand image (X1) getuk singkong terhadap minat genersi muda mengkonsumsi makanan tradisional.

1. Indikator strengthness

Pernyataan 1: Kualitas produk getuk

singkong baik

Pernyataan 2: Saya merekomendasikan produk getuk singkong kepada orang lain

Pernyataan 3: Produk getuk singkong memiliki reputasi yang baik

Pernyataan 4: Produk getuk singkong dapat bersaing dengan produk lain sejenisnya
2. Indikator Uniqueness

Pernyataan 5: Produk getuk singkong unik atau berbeda dari lainnya

Pernyataan 6: Produk getuk singkong mudah untuk dikenali

3. Indikator Favorable

Pernyataan 7: Produk getuk singkong menarik bagi saya

Pernyataan 8: Produk getuk singkong mudah untuk diingat

Pernyataan 9: Saya bersedia untuk mengkonsumsi produk getuk singkong

C. Kuesioner Packaging (X2) getuk singkong terhadap minat genersi muda mengkonsumsi makanan tradisional.

1. Indikator daya tarik praktis

Pernyataan 10: Produk getuk singkong

mudah untuk disimpan

Pernyataan 11: Produk getuk singkong dikemas sesuai dengan porsi dan ukuran yang sesuai

Pernyataan 12: Produk getuk singkong mudah untuk dibawa, dipegang dan dijinjing

Pernyataan 13: Produk getuk singkong terbungkus dengan rapi dan terlindungi

2. Indikator daya tarik visual Pernyataan 14: Produk getuk singkong memiliki ciri khasnya tersendiri

Pernyataan 15: Warna dan bentuk pembungkus produk getuk singkong menarik perhatian

Pernyataan 16: Bentuk produk getuk singkong mudah untuk diingat

Pernyataan 17: Produk getuk singkong memiliki tampilan sederhana namun menarik

Pernyataan 18: Saya dapat dengan mudah mengenali produk getuk singkong

D. Kuesioner minat beli (Y) getuk singkong terhadap minat genersi muda mengkonsumsi makanan tradisional. 
1. Indikator Tertarik Mencari Informasi Tentang Produk

Pernyataan: Saya tertarik untuk mencari tahu mengenai produk getuk singkong

Pernyataan 20: Saya mengumpulkan informasi sebanyak mungkin mengenai produk

2. Indikator mempertimbangkan untuk membeli

Pernyataan 21: Saya mempertimbangkan untuk membeli produk getuk singkong

Pernyataan 22: Saya membandingkan produk getuk singkong dengan produk lain sejenisnya

Pernyataan 23: Saya senang membeli produk getuk singkong ini dibandingkan produk lain sejenisnya

3. Indikator Tertarik Untuk Mencoba Pernyataan 24: Saya tertarik untuk mencoba produk getuk singkong tersebut

Pernyataan 25: Produk getuk singkong memiliki kekhasan yang unik yang menjadi daya jual

Pernyataan 26: Saya percaya produk getuk singkong berkualitas bagus

4. Indikator Ingin Mengetahui Produk Pernyataan 27: Saya ingin mengetahui lebih banyak tentang produk getuk singkong

5. Indikator ingin Membeli Produk Pernyataan 28: Saya ingin untuk membeli produk getuk singkong tersebut

Pernyataan 29: Saya tertarik untuk merekomendasikan produk getuk singkong kepada orang lain

Populasi responden penelitian ini adalah generasi muda yang dalam hal ini akan diambil dari mahasiswa-mahasiswi aktif Sekolah Tinggi Pariwisata Trisakti angkatan 2014 sampai dengan angkatan 2016, berusia 16-24 tahun yang pernah mencari tahu/mengetahui serta pernah mencicipi getuk singkong dan tinggal didaerah Jabodetabek (Jakarta, Bogor, Depok, Tangerang, Bekasi) adalah sebanyak 965 mahasiswa. Sampel ditentukan dengan rumus Slovin dengan margin error $10 \%$, yaitu 91 mahasiswa.

Data yang diperoleh melalui kuesioner akan diolah menggunakan software SPSS versi 24, kemudian diolah dan disajikan secara singkat, padat, jelas dan informatif melalui uji analisis deskriptif, uji validitas, uji reabilitas, analisis regresi linier sederhana, uji hipotesis, analisis regresi linier berganda, analisis koefisien determinasi, uji $\mathrm{T}$, dan uji $\mathrm{F}$.

Uji validitas dilakukan dengan menggunakan tingkat kepercayaan $95 \%$ dimana $\mathrm{df}=\mathrm{n}-2$. Nilai n yang diuji sejumlah 91, sehingga df $=91-2$, sehingga nilai df 89 . Dengan begitu, diperoleh nilai $\mathrm{r}_{\text {tabel }}=0,2061$.

Uji reliabilitas menggunakan tingkat kepercayaan $95 \%$ dengan nilai $r$ tabel, dimana $\mathrm{df}=\mathrm{n}-2$. Nilai n dalam penelitian ini yaitu 91-2, sehingga nilai df 89. Dengan begitu, diperoleh nilai $\mathrm{r}_{\text {tabel }}=$ 0,1735 .

Uji T ini dilakukan dengan membandingkan nilai $t_{\text {hitung }}$ dengan nilai $t_{\text {tabel. }}$. Jika $t_{\text {hitung }}>t_{\text {tabel }}$ maka dapat dinyatakan bahwa variabel mempengaruhi variable yang lainnya. Adapun Nilai $t_{\text {tabel }}$ dapat kita peroleh dengan rumus $=\mathrm{t}(\alpha / 2 ; \mathrm{n}-\mathrm{k}-1)$. Dengan demikian Nilai $\mathrm{t}_{\text {tabel }} \mathrm{t}(0,025 ; 88)$ yaitu sebesar 1,991 .

Uji hipotesis dalam penelitian ini adalah:

$\mathrm{H}_{01} \quad$ : Tidak adanya pengaruh brand image terhadap minat mengkonsumsi makanan tradisional generasi muda.

$\mathrm{H}_{\mathrm{a} 1} \quad$ : Ada pengaruh brand image terhadap minat mengkonsumsi makanan tradisional generasi muda.

$\mathrm{H}_{02} \quad$ : Tidak adanya pengaruh packaging terhadap minat mengkonsumsi makanan tradisional generasi muda.

$\mathrm{H}_{\mathrm{a} 2} \quad$ : Ada pengaruh packaging terhadap minat mengkonsumsi makanan tradisional generasi muda.

$\mathrm{H}_{03} \quad$ : Tidak adanya pengaruh brand image dan packaging terhadap minat mengkonsumsi makanan tradisional generasi muda.

$\mathrm{H}_{\mathrm{a} 3} \quad$ : Ada pengaruh brand image dan packaging terhadap minat 
mengkonsumsi makanan tradisional generasi muda.

Uji $\mathrm{F}$ dilakukan dengan membandingkan antara $\mathrm{F}_{\text {hitung }}$ dengan $\mathrm{F}_{\text {tabel }}$. Apabila $\mathrm{F}_{\text {hitung }}<\mathrm{F}_{\text {tabel }}$ : maka Ho diterima dan Ha ditolak sehingga variabel X1 dan $\mathrm{X} 2$ secara simultan tidak mempengaruhi variabel Y. Apabila $\mathrm{F}_{\text {hitung }}>\mathrm{F}_{\text {tabel }}$, maka Ho ditolak dan Ha diterima sehingga variabel X1 dan X2 secara simultan mempengaruhi variabel $Y$. Untuk mencari $\mathrm{F}_{\text {tabel }}$ dapat menggunakan rumus berikut :

df $1=\mathrm{k}-1$, maka df $1=3-1=2$

df $2=n-k$, maka df $2=91-3=88$

keterangan: Jumlah sampel yang digunakan $(\mathrm{n})=$ 91 dan Jumlah variabel $(\mathrm{k})=3$. Karena pengujian dilakukan pada $\alpha=5 \%$, maka nilai $\mathrm{F}_{\text {tabel }}$ sebesar 3,023. Dan untuk mengetahui $\mathrm{F}_{\text {tabel }}$ dapat kita temukan dengan rumus $\mathrm{F}$ tabel $=\mathrm{F}(\mathrm{k} ; \mathrm{n}-\mathrm{k})$ dan melalui rumus tersebut ditemukan bahwa $\mathrm{F}_{\text {tabel }}=$ $\mathrm{F}(3 ; 88)$ yaitu sebesar 2,71

\section{HASIL DAN PEMBAHASAN}

Pada penelitian ini penulis telah melakukan perubahan Brand Image dan Packaging getuk singkong yang diharapkan dapat meningkatkan minat konsumsi generasi muda untuk mengkonsumsi makanan tradisional. Adapun perubahan Brand Image yang dilakukan adalah dengan merubah bentuk getuk singkong lalu melumuri getuk tersebut dengan coklat dekorasi. Hal ini dapat menambah estetika dari produk tersebut sekaligus juga menambahkan umur dari produk tersebut.

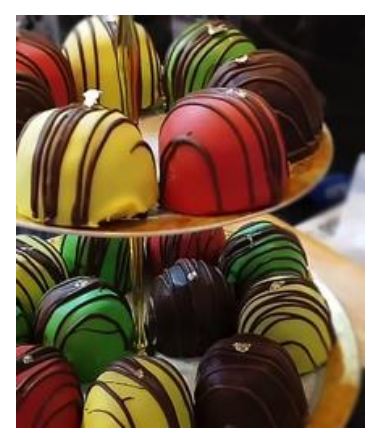

Gambar 1. Modifikasi Brand Image Getuk Singkong

Selain melakukan perubahan pada tampilan atau brand image getuk singkong penulis jug mengganti packaging getuk singkong yang lama. Penggantian ini diharapkan dapat menjadikan produk lebih modern dan juga lebih atraktif.

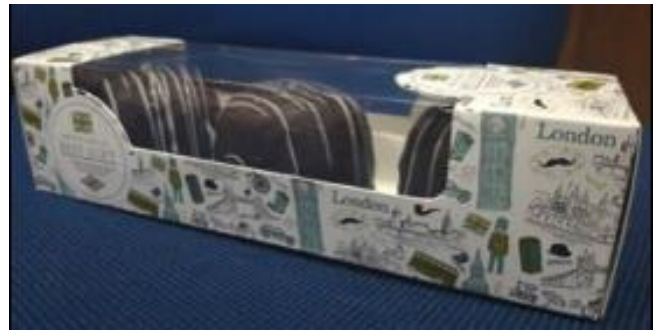

Gambar 2. Modifikasi Packaging Getuk Singkong

Hasil dan pembahasan kuesioner

1. Karakteristik Demografi Responden

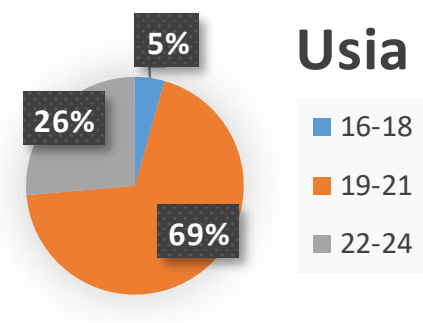

Gambar 3. Usia Responden

Mayoritas responden sebanyak $60 \%$ memiliki usia diantara 19-21 tahun, sedangkan minoritas responden sebesar 5\% memiliki usia 16-18 tahun.

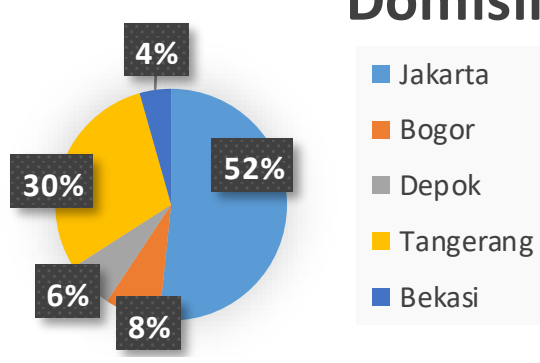

Gambar 4. Domisili Responden

Mayoritas domisili responden berdomisili di Jakarta sebesar 52\%, lalu diikuti dengan Tangerang, Bogor, Depok, dan Bekasi.

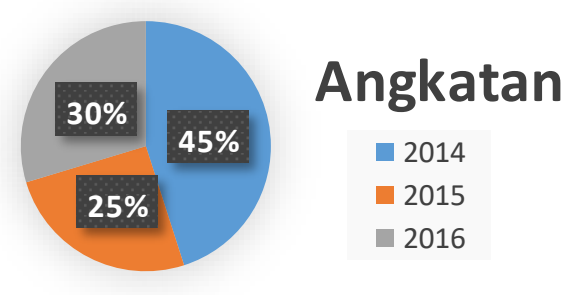




\section{Gambar 5. Angkatan Responden}

Mayoritas responden sebanyak $45 \%$ adalah angkatan 2014, selanjutnya sebanyak 30\% adalah angkatan 2016, dan 25\% angkatan 2015.

2. Kuesioner Brand Image (X1) getuk singkong terhadap minat genersi muda mengkonsumsi makanan tradisional.

- Uji validitas

Uji validitas dilakukan pada 9 pernyataan yang menyangkut variabel X1 dinyatakan valid, karena angka pada kolom corrected item-total correlation lebih besar dari 0,2061.

Tabel 1. Data uji validitas variable Brand

\begin{tabular}{ccc}
\multicolumn{3}{c}{ Image (X1) } \\
\hline No & Pernyataan & $\begin{array}{c}\text { Corrected Item-Total } \\
\text { Correlation }\end{array}$ \\
\hline 1 & 1 & 0.712 \\
\hline 2 & 2 & 0.763 \\
\hline 3 & 3 & 0.748 \\
\hline 4 & 4 & 0.693 \\
\hline 5 & 5 & 0.650 \\
\hline 6 & 6 & 0.541 \\
\hline 7 & 7 & 0.753 \\
\hline 8 & 8 & 0.768 \\
\hline 9 & 9 & 0.649
\end{tabular}

- Uji reliabilitas

Berdasarkan hasil olah data menggunakan SPSS 24, maka didapat Cronbach's Alpha variabel X1 (Brand Image) yaitu 0,912 , sehingga dapat disimpulkan bahwa 9 pernyataan yang menyangkut variabel X1 (Brand Image) dinyatakan sangat reliabel.

- Analisis Statistik Deskriptif Hasil analisis statistik deskriptif dapat dilihat dari Tabel 2.

Tabel 2. Hasil Analisis Statistik Deskriptif Variabel X1

\begin{tabular}{|c|c|c|c|}
\hline No & Pernyataan & Mean & $\begin{array}{l}\text { Std. } \\
\text { Deviation }\end{array}$ \\
\hline 1 & 1 & 4.55 & 0.873 \\
\hline 2 & 2 & 4.36 & 1.111 \\
\hline 3 & 3 & 4.20 & 1.088 \\
\hline 4 & 4 & 4.33 & 1.055 \\
\hline 5 & 5 & 4.65 & 1.004 \\
\hline 6 & 6 & 4.22 & 1.133 \\
\hline 7 & 7 & 4.22 & 1.209 \\
\hline$\overline{8}$ & 8 & 4.34 & 1.166 \\
\hline 9 & 9 & 4.46 & 1.025 \\
\hline \multicolumn{4}{|c|}{$\begin{array}{l}\text { nilai mean dari masing-masing } \\
\text { pernyataan menunjukkan kecenderungan } \\
\text { perilaku responden dalam menjawab } \\
\text { pernyataan yang diberikan. Nilai mean } \\
\text { yang paling tinggi adalah } 4,65 \text { yang } \\
\text { dimiliki Penyataan } 5 \text { "Produk getuk } \\
\text { singkong unik atau berbeda dari prosuk } \\
\text { lain sejenisnya", hal iniberarti responden } \\
\text { sangat setuju dengan pernyataan tesebut. } \\
\text { Nilai mean yang paling rendah adalah } \\
4,20 \text { yang dimiliki Penyataan } 3 \text { "Produk } \\
\text { getuk singkong memiliki reputasi yang } \\
\text { baik", hal ini berarti responden masih } \\
\text { belum terlalu setuju dengan pernyataan } \\
\text { tesebut dikarenakan reputasi yang } \\
\text { dirasakan responden belum cukup baik. }\end{array}$} \\
\hline
\end{tabular}

- Analisis linier sederhana

Berdasarkan data olahan SPSS 24, maka persamaan regresi linier sederhana antara variable Brand Image (X1) terhadap Minat Konsumsi Generasi Muda (Y) dengan persamaan sebagai berikut :

$$
\mathrm{Y}=1,086+0,720 \mathrm{X}
$$

Dari persamaan diatas, dapat dijelaskan bahwa jika Brand Image (X1) konstan atau tidak mengalami perubahan, maka Minat Konsumsi Generasi Muda (Y) yang tercipta adalah sebesar 1,086 satuan. Nilai koefisien regresi Brand 
Image (X1) sebesar 0,720 ini mengindikasikan bahwa setiap terjadi kenaikan satu satuan penilai responden terhadap Brand Image (X1), maka akan meningkatkan Minat Konsumsi Generasi Muda sebesar 0,720. Jika Brand Image semakin meningkat maka akan semakin meningkatkan Minat Konsumsi Generasi Muda dan sebaliknya jika Brand Image menurun maka akan menurunkan Minat Konsumsi Generasi Muda.

- Analisis koefisien determinasi

Dari output hasil olahan data menggunakan SPSS 24, maka diperoleh koefisien determinasi $\left(\mathrm{R}^{2}\right)$ sebesar 0,566 yang mengandung pengertian bahwa variabel brand image (X1) berkontribusi terhadap variabel Y 56,6\% sedangkan $43,4 \%$ dipengaruhi variabel lain.

- Uji T

Uji $t$ dilakukan untuk mengetahui pengaruh antara variabel Brand Image (X1) terhadap variabel Minat Konsumsi Generasi Muda (Y). Berdasarkan hasil olahan data menunjukkan bahwa $t_{\text {hitung }}>t_{\text {tabel }}(10,763>1,991)$ sehingga dapat dinyatakan bahwa variabel Brand Image (X1) mempunyai pengaruh secara parsial terhadap Minat Konsumsi Genarasi Muda(Y). Data ini menunjukan bahwa Brand Image yang ada pada produk getuk singkong menjadi salah satu sarana penilaian yang penting bagi konsumen dalam menentukan pilihan produk yang akan dibeli dan juga dapat menunjukkan untuk dapat lebih memperhatikan mengenai peran dari Brand Image yang ada dalam produknya dimana dapat kita lihat melalui 3 indikator penilaian yaitu Strenghness (Kekuatan), Uniqueness (Keunikan) dan juga Favorable (Kesukaan).

- Uji Hipotesis

Berdasarkan uji $\mathrm{T}$ juga dapat ditarik kesimpulan bahwa hipotesis $\mathrm{H}_{\mathrm{a} 1}$ yaitu "ada pengaruh brand image terhadap minat generasi muda mengkonsumsi makanan tradisional" diterima.

3. Kuesioner Packaging (X2) getuk singkong terhadap minat genersi muda mengkonsumsi makanan tradisional

- Uji validitas

Uji validitas dilakukan pada9 pernyataan yang menyangkut variabel X2 dinyatakan valid, karena angka pada kolom corrected item-total correlation lebih besar dari 0,2061.

Tabel 3. Data uji validitas variable Packaging (X2)

\begin{tabular}{|c|c|c|}
\hline No & Pernyataan & $\begin{array}{c}\text { Corrected Item-Total } \\
\text { Correlation }\end{array}$ \\
\hline 1 & 10 & 0.546 \\
\hline 2 & 11 & 0.693 \\
\hline 3 & 12 & 0.683 \\
\hline 4 & 13 & 0.623 \\
\hline 5 & 14 & 0.756 \\
\hline 6 & 15 & 0.676 \\
\hline 7 & 16 & 0.756 \\
\hline 8 & 17 & 0.792 \\
\hline 9 & 18 & 0.693 \\
\hline
\end{tabular}

- Uji reliabilitas

Berdasarkan hasil olah data menggunakan SPSS 24, maka didapat Cronbach's Alpha variabel X2 (Packaging) yaitu 0,909, sehingga dapat disimpulkan bahwa 9 pernyataan yang menyangkut variabel X2 (Packaging) dinyatakan sangat reliabel.

- Analisis Statistik Deskriptif Hasil analisis statistik deskriptif dapat dilihat dari Tabel 4.

Tabel 4. Hasil Analisis Statistik Deskriptif Variabel X2 


\begin{tabular}{cccc}
\hline No & Pernyataan & Mean & $\begin{array}{l}\text { Std. } \\
\text { Deviation }\end{array}$ \\
\hline 1 & 10 & 4.30 & 1.059 \\
\hline 2 & 11 & 4.49 & 0.861 \\
\hline 3 & 12 & 4.82 & 0.877 \\
\hline 4 & 13 & 4.65 & 0.935 \\
\hline 5 & 14 & 4.80 & 1.013 \\
\hline 6 & 15 & 4.75 & 1.050 \\
\hline 7 & 16 & 4.55 & 1.036 \\
\hline 8 & 17 & 4.65 & 1.068 \\
\hline 9 & 18 & 4.55 & 1.067
\end{tabular}

Nilai mean yang paling tinggi adalah 4,82 yang dimiliki Penyataan 12 "Produk getuk singkong mudah untuk dibawa, dipegang dan dijinjing", hal ini berarti responden setuju dengan pernyataan tesebut. Pernyataan lain yang memiliki nilai mean paling rendah adalah 4,30 yang dimiliki Pernyataan 10 "Produk getuk singkong mudah untuk disimpan", hal ini berarti responden masih belum terlalu setuju dengan pernyataan tesebut dikarenakan responden belum dapat merasakan secara langsung dalam penyimpanan produk tersebut serta terdapatnya berbagai sudut pandang responden yang mungkin terjadi.

- Analisis linier sederhana

Berdasarkan data olahan SPSS 24, maka persamaan regresi liniear sederhana antara variabel Packaging (X2) terhadap Minat Konsumen Generasi Muda (Y) dengan persamaan sebagai berikut:

$$
\mathrm{Y}=0,876+0,727 \mathrm{X}
$$

Dari persamaan diatas, dapat dijelaskan bahwa jika Packaging (X2) konstan atau tidak mengalami perubahan, maka Minat Konsumsi Generasi Muda (Y) yang tercipta adalah sebesar 0,876 satuan. Nilai koefisien regresi Packaging (X2) sebesar 0,727 ini mengindikasikan bahwa setiap terjadi kenaikan satu satuan penilai responden terhadap Packaging (X2), maka akan meningkatkan Minat Konsumsi Generasi Muda sebesar 0,727. Jika Packaging semakin meningk at maka akan semakin meningkatkan Minat Konsumsi Generasi Muda dan sebaliknya jika Packaging menurun maka akan menurunkan Minat Konsumsi Generasi Muda.

- Analisis koefisien determinasi

Dari output hasil olahan data menggunakan SPSS 24, maka diperoleh koefisien determinasi $\left(\mathrm{R}^{2}\right)$ sebesar 0,489 yang mengandung pengertian bahwa variabel $\mathrm{Y}$ dipengaruhi oleh variabel $\mathrm{X} 2$ sebesar $48,9 \%$ sedangkan $51,1 \%$ dipengaruhi variabel lain.

- Uji T

Uji t dilakukan untuk mengetahui pengaruh antara variabel Packaging (X2) terhadap variabel Minat Konsumsi Generasi Muda (Y). Berdasarkan hasil olahan data menunjukkan bahwa $t_{\text {hitung }}>t_{\text {tabel }}(9,237>1,991)$ sehingga dapat dinyatakan bahwa variabel Packaging (X1) mempunyai pengaruh secara parsial terhadap Minat Konsumsi Genarasi Muda (Y). Ini menunjukan bahwa Packaging dari getuk singkong sudah cukup baik. Selain itu semua faktorfaktor yang ada dalam Packaging getuk singkong telah menjadi salah satu fokus utama persaingan produk dengan produk lain sejenisnya. Hal ini juga memperlihatkan bahwa konsumen sangat memperhatikan daya tarik produk yang ada baik itu daya tarik praktis maupun daya tarik visual yang ada sebelum memutuskan untuk mengkonsumsi produk tersebut.

- Uji Hipotesis

Berdasarkan uji $\mathrm{T}$ di atas juga dapat ditarik kesimpulan bahwa hipotesis $\mathrm{H}_{22}$ yaitu "ada pengaruh packaging terhadap 
minat generasi muda mengkonsumsi makanan tradisional" diterima.

4. Kuesioner Minat beli (Y) getuk singkong terhadap minat genersi muda mengkonsumsi makanan tradisional.

- Uji validitas

Uji validitas dilakukan pada 11 pernyataan yang menyangkut variabel $\mathrm{Y}$ dinyatakan valid, karena angka pada kolom corrected item-total correlation lebih besar dari 0,2061.

Tabel 5. Data uji validitas variable minat

\begin{tabular}{ccc}
\multicolumn{3}{c}{ beli (Y) } \\
\hline No & Pernyatan & $\begin{array}{c}\text { Corrected Item-Total } \\
\text { Correlation }\end{array}$ \\
\hline 1 & 19 & 0.808 \\
\hline 2 & 20 & 0.647 \\
\hline 3 & 21 & 0.381 \\
\hline 4 & 22 & 0.590 \\
\hline 5 & 23 & 0.775 \\
\hline 6 & 24 & 0.715 \\
\hline 7 & 25 & 0.726 \\
\hline 8 & 26 & 0.613 \\
\hline 9 & 27 & 0.822 \\
\hline 10 & 28 & 0.804 \\
\hline 11 & 29 & 0.771 \\
\hline
\end{tabular}

- Uji reliabilitas

Berdasarkan hasil olah data menggunakan SPSS 24, maka didapat Cronbach's Alpha variabel Y (minat beli) yaitu 0,925 , sehingga dapat disimpulkan bahwa 11 pernyataan yang menyangkut variable $\mathrm{Y}$ (minat beli) dinyatakan sangat reliabel.

- Analisis Statistik Deskriptif Hasil analisis statistik deskriptif dapat dilihat dari Tabel 6.

Tabel 6. Hasil Analisis Statistik Deskriptif Variabel Y

\begin{tabular}{cccc}
\hline No & Pernyataan & Mean & $\begin{array}{l}\text { Std. } \\
\text { Deviation }\end{array}$ \\
\hline 1 & 19 & 4.23 & 1.034 \\
\hline 2 & 20 & 3.60 & 1.201 \\
\hline 3 & 21 & 4.36 & .796 \\
\hline 4 & 22 & 4.01 & 1.150 \\
\hline 5 & 23 & 3.76 & 1.139 \\
\hline 6 & 24 & 4.51 & 1.058 \\
\hline 7 & 25 & 4.53 & 0.981 \\
\hline 8 & 26 & 4.65 & 0.887 \\
\hline 9 & 27 & 4.19 & 1.084 \\
\hline 10 & 28 & 4.33 & 1.096 \\
\hline 11 & 29 & 4.41 & 1.022 \\
\hline
\end{tabular}

Nilai mean yang paling tinggi adalah 4,65 yang dimiliki Penyataan 26 "Saya percaya produk getuk singkong berkualitas bagus", hal ini berarti responden setuju dengan pernyataan tesebut. Nilai mean yang paling rendah adalah 3,60 yang dimiliki Penyataan 20 "Saya mempertimbangkan untuk membeli produk getuk singkong", hal ini berarti responden masih belum terlalu setuju dengan pernyataan tesebut yang mungkin diakibatkan oleh banyaknya variasi makanan tradisional lain di daerah Jabodetabek sehingga sulit menentukan pilihan produk yang ingin dibeli.

- Analisis regresi linier berganda Berdasarkan data olahan SPSS 24, maka persamaan regresi linier berganda berganda antara variabel Brand Image (X1) dan Packaging (X2) terhadap Minat Konsumsi Generasi Muda (Y) dengan persamaan sebagai berikut:

$$
\mathrm{Y}=0,224+0,496 \mathrm{X} 1+0,399 \mathrm{X} 2
$$

Dari hasil persamaan tersebut dan hasil analisis sebelumnya maka didapatkan hasil : 
a) Jika variabel Brand Image meningkat sebesar 0,496 dengan asumsi variabel Packaging konstan, maka akan mampu meningkatkan Minat Beli Konsumen sebesar 0,496.

b) Jika variabel Packaging meningkat 0,399 dengan asumsi variabel Brand Image konstan, maka akan mampu meningkatkan Minat Konsumsi Generasi Muda 0,399.

- Analisis koefisien determinasi

Dari output hasil olahan data menggunakan SPSS 24, maka diperoleh koefisien determinasi $\left(\mathrm{R}^{2}\right)$ sebesar 0,658 yang mengandung pengertian bahwa variabel $\mathrm{Y}$ dipengaruhi oleh variabel $\mathrm{X} 1$ dan X2 sebesar $65,8 \%$ sedangkan $34,2 \%$ dipengaruhi variabel lain.

\section{- Uji F}

Dari output hasil olahan data menggunakan SPSS 24, maka $F$ hitung $(84,655)>F_{\text {tabel }}(2,71)$. Dan dari data tersebut dapat kita lihat bahwa $\mathrm{F}_{\text {hitung }}>\mathrm{F}$ tabel : maka Ho ditolak dan Ha diterima sehingga variabel $\mathrm{X} 1$ dan $\mathrm{X} 2$ secara simultan mempengaruhi variabel $\mathrm{Y}$. Selain itu juga dapat ditarik kesimpulan bahwa hipotesis $\mathrm{H}_{\text {a3 }}$ yaitu "ada pengaruh brand image dan packaging terhadap minat generasi muda mengkonsumsi makanan tradisional" diterima. Pengaruh yang positif ini akan semakin meningkat dengan dimanfaatkannya segala faktor yang ada baik itu didalam Brand Image ataupun Packaging guna menjadikan produk getuk singkong yang ada dapat bersaing dengan produk lain sejenisnya dan juga dapat meningkatkan minat generasi muda untuk dapat mengkonsumsi produk tersebut. Dengan keduanya dapat dimaksimalkan, dapat dipastikan bahwa produk tersebut akan dapat berkembang dan memiliki reputasi yang sangat baik

\section{SIMPULAN}

1. Tingkat pengaruh yang diberikan oleh variabel X1 (Brand Image) terhadap variabel Y (Minat Konsumsi Generasi Muda) dalam setiap satu kali kenaikan satuan adalah sebesar 0,720 serta variabel brand image berkontribusi sebesar $56,6 \%$ sedangkan 43,3\% lainnya dipengaruhi oleh variabel lain di luar brand image.

2. Tingkat pengaruh yang diberikan oleh variabel X2 (Packaging) terhadap variabel Y (Minat Konsumsi Generasi Muda) dalam setiap satu kali kenaikan satuan adalah sebesar 0,727 serta packaging berkontribusi sebesar $48,9 \%$ sedangkan $51,1 \%$ dipengaruhi oleh variabel lain di luar packaging.

3. Tingkat pengaruh yang diberikan oleh kedua variabel yang ada yaitu variabel X1 (Brand Image) dan variabel X2 (Packaging) terhadap variabel Y (Minat Konsumsi Generasi Muda) dalam setiap satu kali kenaikan satuan adalah sebesar 0,496 untuk variabel X1 dan sebesar 0,399 untuk variabel X2 selain itu brand image dan packaging berkontribusi secara simultan terhadap minat generasi muda mengkonsumsi makanan tradisional $65,8 \%$ sedangkan $34,2 \%$ dipengaruhi oleh variabel lain di luar brand image dan packaging.

4. Berdasarkan dari hasil analisis antara variabel $\mathrm{X} 1$ (Brand Image) dan X2 (Packaging) terhadap variabel Y maka dapat disimpulkan bahwa brand image (X1) memiliki pengaruh yang lebih besar terhadap minat konsumsi generasi muda (Y) dengan tingkat kontribusi sebesar 56,6\%, lebih besar kontribusinya daripada packaging (X2) yang berkontribusi terhadap variabel Y sebesar 48,9\%.

\section{DAFTAR PUSTAKA}

Ali, Hasan. 2013. Marketing dan Kasus-Kasus Pilihan. Yogyakarta. CAPS (Center For Academic Publishing Service)

Ajzen. I and M. Fishbein. 1975. Belief, Attitude, Intention and Behavior: An Introduction to theory and Research. Philippines: AddisonWesley Publishing.

Angipora, Maskus, P. 2006. "Dasar-Dasar Pemasaran”. Edisi Pertama. Jakarta. PT. Raja Grafindo Grafada. 151. 
Assael, H. 1998. The consumer behavior and marketing action. Unites States. SouthWestern College publishing. pp.23-24.

Data Jumlah Mahasiswa Aktif Angkatan 2014 sampai dengan 2016 - Bagian Administrasi Akademik Sekolah Tinggi Pariwisata Trisakti.

Dewi asyachroni.wordpress.com/2012/10/12/baura n-pemasaran/

Gardjito, Murdijati, dkk. 2013. Pangan Nusantara Karakteristik dan Prospek untuk Percepatan Diversifikasi Pangan. Jakarta: Kencana Prenada Media Group

Gedard, Kathryn \& Geldard, David. 2011. "Konseling Remaja”. Yogyakarta. Pustaka Pelajar.

Hasan, Ali. 2013. Marketing dan Kasus-Kasus Pilihan.Yogyakarta. Caps Publishing.

Keller, Kevin Lane. 2013. "Strategi Brand Management (Building, Measuring and Managing Brand Equity)”. Fourth Edition. Pactise Hall. New Jersey.

Kotler, P. and Kevin Keller. 2008, Marketing Management, Thirteenth Edition. Pearson Education Inc.

Kotler, Philip dan Armstrong, Gary. 1997. "Prinsip-Prinsip Pemasaran". Jakarta. Erlangga.

Kotler, Philip. 1995. "Manajemen Pemasaran". Jakarta. Erlangga
Kuhnlein HV, Receveur O. 1996. "Dietary Change and Traditional Food Systems of Indegenous Peoples". Annu Rev Nutr 16:147442

Peter, J.P and Jerry C. Olson. 2010. Consumer Behavior and Marketing Strategy $9^{\text {th }}$ Edition. McGraw Hill Higher Education.

Saladin, Djaslim, 1996, Unsur-Unsur Inti Pemasaran dan Manajemen Pemasaran, Bandung: Mandar Maju.

Sastrohamidjojo, H. 1991. "Spektroskopi". Yogyakarta. Penerbit Liberty.

Schiffman, L. G and Leslie Lazar Kanuk. 2008. Consumer behavior. New Jersey: Prentice Hall International.

Syarief, R dan A. Irawati. 1988. "Pengetahuan Bahan Untuk Industri Pertanian”. Jakarta. Mediyatama.

Temporal and Lee. 2002. Hi-Tech Hi-Touch Branding menciptakan Kekuatan Merek Dalam Era Teknologi. Jakarta : Salemba Empat

Tjiptono, Fandy \& Candra Gregorius. 2005. "Service, Quality and Satisfaction". Yogyakarta. Penerbit Andi. 49.

Wirya, Iwan. 1999. "Kemasan yang Menjual : Menang Bersaing Melalui Kemasan”. Jakarta. Gramedia Pustaka Utam 